\title{
The Euro Zone Economic Crisis and Sub-Saharan Africa's Real Economy: Analysis and the Way Forward
}

\author{
Ashford C. Chea \\ Benedict College, School of Business \& Economics \\ 1340 Longcreek Drive \#508, Columbia, SC 29210 USA \\ Tel: 916-856-2197Ｅ-mail: Ashford.chea@yahoo.com
}

Received: December 2, 2014 Accepted: December 18, 2014

doi:10.5296/ber.v5i2.8594 URL: http://dx.doi.org/10.5296/ber.v5i2.8594

\begin{abstract}
The purpose of the paper was to investigate if there were some negative impact of the euro zone economic crisis on sub-Saharan Africa's (SSA) real economy. The evidence revealed that the euro zone crisis had affected sub-Saharan Africa economy in terms of trade, development assistance, and remittance. The conclusion derived from the evidence is that SSA's economic growth was negatively affected slightly. This was due to prudential policies implemented by SSA policy-makers. The article begins with the historical background of the euro zone economic crisis and its root causes. It then provides an analysis of the transmission channels of the crisis and its impact on SSA's economies. This is followed by a discussion of the policy responses to the crisis by SSA's policy-makers. The paper concludes with an analysis of SSA's recent economic performance and the way forward for long term growth and sustainable development.
\end{abstract}

Keywords: Eurozone, Debt, Crisis, sub-Saharan Africa, Economies, Impact, Growth, Development

\section{Introduction}

One of the major factors contributing to the euro zone debt crisis was the 2007-2008 global financial and economic crises, which in itself was one of the worst crises to hit the global economy. The global financial crisis and economic downturn emanated from the subprime mortgage crisis in the United States and spread to European markets as well as the rest of the world. The problem then culminated in a debt crisis as the sovereign debt levels of some of the world's largest economies increased sharply, placing them at risk of default. In Europe, the crisis started with the collapse of the banking system in Iceland in 2008 and spread to 
other European countries including Greece, Ireland, and Portugal in 2009. The crisis reached its first apex in early 2010, as a result of Greece's large structural deficit and the increasing cost of financing government debt. The Greece government used deficit spending to increase the living standards of its population as the deficit financed unemployment benefits, higher public sector salaries and pension, and hence served to sustain an uncompetitive labor market (UNECA, 2012).

\subsection{Objectives of the Paper}

The objectives of the paper were to analyze the following: (1) the channels of transmission of the euro zone debt crisis to SSA; (2) the impact of the crisis on SSA economies; (3) SSA policy responses to the crisis and (4) policy lessons, implications, and recommendation for the way forward.

\section{A Brief Background of the Euro Zone Debt Crisis}

The Eurozone crisis was an outcome of two fundamental underpinning situations.

First, the fiscal situation - the fiscal metrics of many euro area countries were deteriorating in the past years. This culminated into the bailing out of Ireland and a Trioka program for Greece, including a very significant write-off. Most euro area countries had debt to GDP ratios in excess of 60 percent and this included even the stronger anchor countries such as Germany and France. In the case of Greece, Ireland, Italy, Portugal and Spain, the fiscal situation also got reflected in higher borrowing costs that made any fiscal stimulus a non-option for policy makers.

Second, the growth situation-Growth outcomes were disappointing in the euro area, to say the least. Data suggest that there could have been further contraction in growth while global growth was not been as supportive to the euro economy. There was also a policy dilemma of balancing fiscal consolidation and providing support to the economy to continue growing. With financial markets reluctant to lend to fiscally weak sovereigns, borrowing costs had risen to the point that it raised the issue of affordability and sustainability. This left countries to choose a path of austerity to regain credibility. As these austerity measures kicked in, developed economies were getting pushed back into recession with implications for the rest of the world (Kganyago, 2012).

\section{Research Method Applied and Outcomes Obtained}

This paper relied on the literature review of current relevant article focusing on the euro zone debt crisis and its effects on SSA in particular. Except where a source was needed specifically for its perspective on broad issues pertinent to euro zone economic meltdown and SSA, the author screened papers by "euro zone debt crisis and SSA" and by numerous variant of keywords, focusing particularly on SSA. Source papers included refereed research studies, empirical reports, and articles from professional journals. Since the literature relating to the euro zone economic crisis is voluminous, the author used several decision rules in choosing articles. First, because global economic forces are changing fast in today's environment, the author used mostly sources published from 2009-2014, except where articles were needed for 


\section{Mll Macrothink}

Business and Economic Research

ISSN 2162-4860

2015, Vol. 5, No. 2

their historical perspectives. Second, given the author's aim to provide a practical understanding of the main issues underpinning the euro zone economic crisis and SSA, he included, in order or priority: refereed empirical research papers, reports, and other relevant literatures on current trends in the euro zone area and resources flow to SSA. The resulting materials included a large quantity of journal articles, empirical reports, and professional documents. Both a thematic and structured approaches were used to examine, separate and choose which sources to review and include in this article. All materials were then grouped by key words such as euro zone, debt crisis, impact, SSA economies, growth, and development for the purpose of analysis. As a result, all of the referenced sources provided the required information from which outcomes (i.e. evidences and conclusions) were derived. To get some perspective on the roots causes and current state of the euro zone economic crisis and its impact on SSA, the author began with the review of the current literature.

\section{The Causes of the Euro Zone Debt Crisis}

The euro zone crisis can be rooted back to four main reasons. First, as Feldstein (2012) argued, the monetary union per se, with the restrictions that it imposes, embeds its own reasons for unavoidable failure; second, the weak institutional framework of the euro zone as spelled out in the Maastricht treaty establishing the currency union; third, the fragile European banking system which indulged itself in huge lending to European governments bringing the whole zone into a vicious cycle and; fourth, structural weaknesses existing in a number of euro zone economies. Similarly, the crisis in Europe reflects primarily the reaction of financial markets to over-borrowing by private households, the financial sector and government in periphery countries of the euro zone (Weidmann, 2012). Proponents of this view argue that if countries had balanced their budgets and avoided the temptation to create a welfare state, excessive private spending would not have occurred and investors and banks would have been more aware of the risks involved (Wolf, 2012).

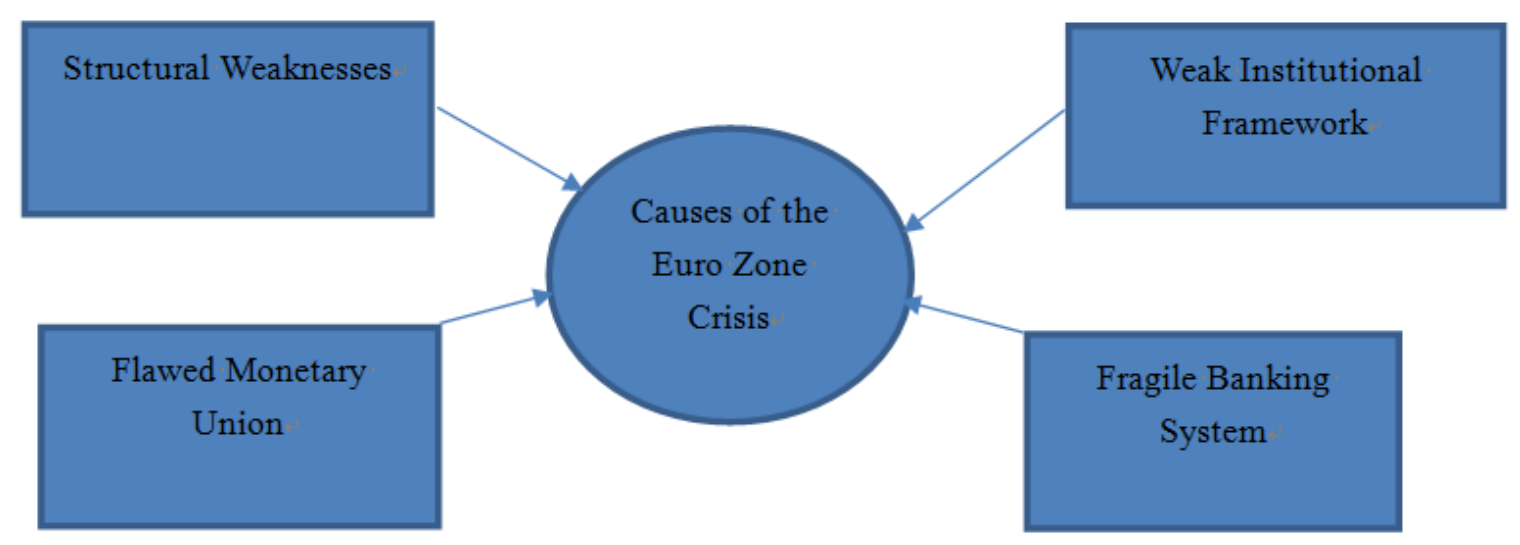

Figure 1. Causes of the Euro Zone Economic Crisis. Author's Construct.

\section{The Channels of Transmission of Euro Zone Debt Crisis to SSA's Real Economy}

Slower growth in euro zone countries affected SSA economies mainly through five channels: trade, liquidity, sovereign risk, foreign direct investment and remittance, and volatility of 
portfolio flows, stock markets and exchange rates.

Trade - slower economic growth in euro zone countries resulted in lower demand for SSA's exports. This constituted the most important transmission channel through which SSA economies were impacted. SSA remains the least diversified region in terms of market access (AfDB Brief, 2012). For example, when global crisis set in, export growth from SSA economies declined from an annual average of 7.0 percent between 2000 and 2007 to only 1.4 percent between 2008 and 2010. This was a significant slow-down. Much of this deceleration came from slower growth in Europe (Kganyago, 2012).

Tight liquidity---The contagion effect of the European debt crisis on the SSA banking sector depends on the extent to which SSA banks were integrated into the European banking system. The presence of European banks is strong in some SSA countries, such as Mozambique, Madagascar, Botswana, Ghana, Cameroon, Rwanda, Zambia and Tanzania, where these banks represent over half of total bank assets. All these countries were partly vulnerable to a tightening of credit markets that follow on the European debt crisis.

Sovereign risk---Sovereign risks to SSA countries rose from three potential sources: (i) contraction in official development assistance (ODA) flows from Europe, (ii) decline in trade-related tax revenues for SSA governments, and (iii) higher cost of borrowing on the global credit markets. The European debt crisis made the above situations even worse.

FDI and Remittances---The deterioration of the debt crisis in the euro zone surely sustained the downward trend in FDI flows to SSA. The downturn expected was dampened by the emerging trend among investors being bullish about bonds issued by agencies based in SSA (AfDB Brief, 2012). Moreover, FDI flows from European Union to SSA were 11.5 billion euro in 2010 and this was a decline from 13.1 billion euro the previous year; and these flows of FDI were mainly to South Africa. To SSA as a whole, FDI inflows reached 21.3 euro in 2010. Positive long-term growth prospects in SSA should attract higher levels of FDI in the future. Forthcoming trends will be seen in countries like Brazil, India, and China's investments into SSA. As market growth continues and investment opportunities expand one should expect to see complementary investments by European firms (Regional Economic Outlook, 2011). In terms of the remittances, a deepening of the debt crisis led to a reduction in remittance flows to SSA, the magnitude of which is hard to predict. Similarly, both Eastern and Southern Africa suffered from fall in remittances. During the 1980s, for instance, international remittances covered 80 percent of the current account deficit of Botswana; they were equal to almost three-quarters of total commodity exports earnings in Sudan; and constituted more than half of Lesotho's foreign exchange earnings. Some studies estimates earnings from remittances to be as high as total official development aid to SSA.

Portfolio flows, stock market and exchange rate volatility---Sharp fluctuation of the euro eroded the earnings for important sectors in SSA. Moreover, exchange rate movements also posed new challenges and opportunities for SSA economies. Euro depreciation against the dollar affected trade flows in developing economies in two opposing directions. On the one hand, those countries with currencies pegged to the euro actually benefit from weaker euro that made their exports more competitive in world markets. This was the case for crude oil, 
cocoa, coffee and groundnut exports from CFA zone countries of West Africa. On the other hand, countries with dollar-based exports suffered from an appreciation of the dollar against the euro (The African Economist, 2012).

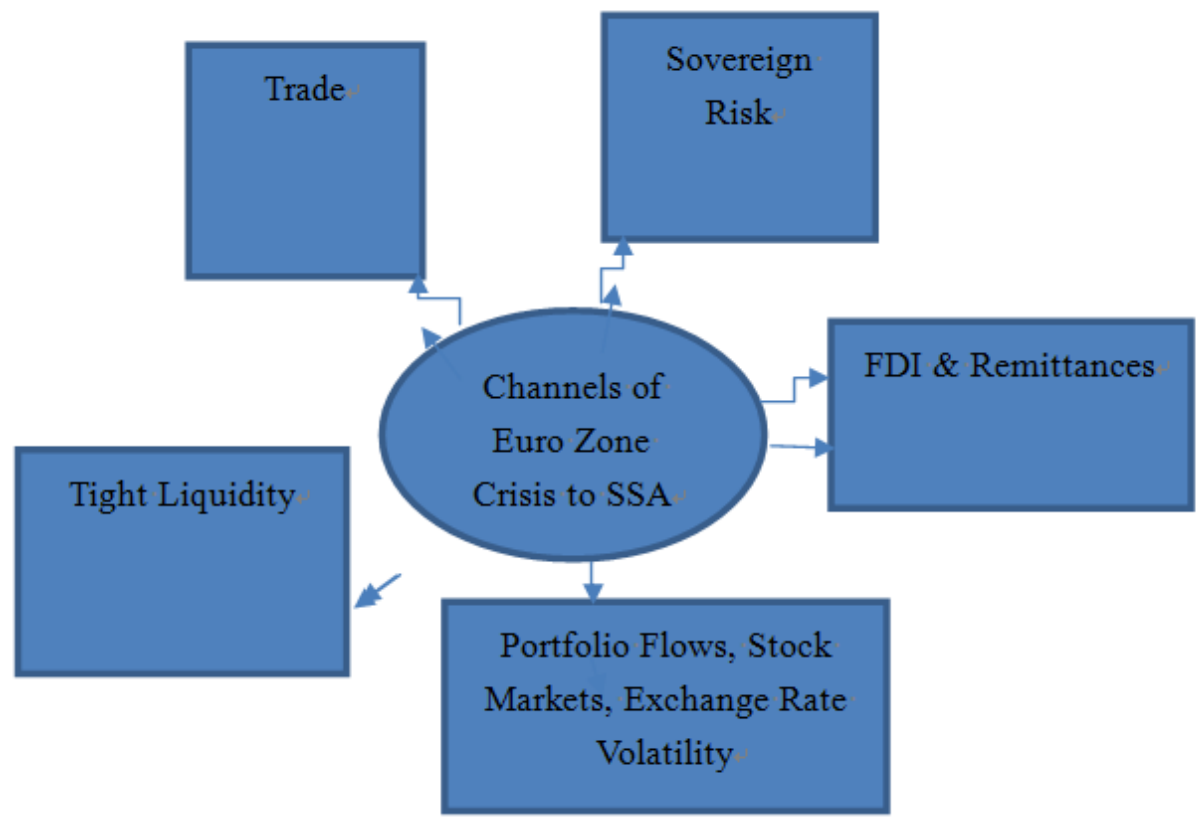

Figure 2. Channels of Transmission of the Euro Zone Crises to SSA Real Economy. Author's Construct

\section{The Impact of the Euro Zone Debt Crisis on SSA Real Economy}

The impact euro area crisis had on SSA economies so far was fairly limited. While the economic recovery has temporarily stalled in parts of Europe and growth slowed in North America, the IMF forecasts emerging and developing economies to grow by 5.4 percent in 2012 - down from 6.2 percent in 2011 - and by 5.9 percent in 2013. SSA was expected to grow by 5.5 percent in 2012 (compared with 4.9 percent in 2011) and was projected to grow further by 5.3 percent in 2013 (Kganyago, 2012). Yet, the effect on other non-EU nations was material because of the pivotal role the EU plays in many SSA economies in terms of linkages such as trade, development aid, and finance.

Table 1. Impact of Euro Zone Crisis on SSA Economic Growth Rates. Source: Author's Construct.

\begin{tabular}{|l|l|l|l|}
\hline & 2011 & 2012 & 2013 \\
\hline Emerging Economies Growth Rates & $6.2 \%$ & $5.4 \%$ & $5.9 \%$ \\
\hline Developing Economies Growth Rates & $6.2 \%$ & $5.4 \%$ & $5.9 \%$ \\
\hline SSA Growth Rates & $4.9 \%$ & $5.5 \%$ & $5.3 \%$ \\
\hline
\end{tabular}

However, if the debt crisis in Europe turns into a more serious economic crisis, SSA economies should expect significant reductions in ODA over the coming years. This is particularly important considering the country breakdowns of ODA. For example, 80 percent of the aid provided by Ireland goes to SSA, while Belgium, France, Portugal and the United 
Kingdom are among the top 10 donor countries for aid to SSA. Currently, a handful of countries - Italy, France, and Iceland - have reduced their bilateral assistance to SSA owing to the debt crisis in Europe. In terms of sectorial allocations, the majority of aid to SSA was spent on the social sector, which includes health, education, population programs, water and sanitation. A reduction in expenditure in these sectors further hindered efforts to alleviate poverty. In addition, revenues from domestic resources remain minimal, adding to the pressures that many SSA governments faced in meeting fiscal demands that came from reduction in ODA. The debt crisis in the euro area also made it even more difficult to prioritize and allocate resources to tackle climate change and other environmental challenges faced by SSA (UNECA, 2012).

Based on the above analysis, if there were to be a further economic downturn, poor countries, including SSA, could suffer in several ways:

1. While low-income and lower-middle income countries have been able to withstand the economic shocks of the past years relatively well, their growth and ability to develop will be invariably affected if the world economy - and this time including the major emerging economies - were to suffer a pronounced cool-down;

2. A particularly worrying scenario would see commodity prices increase further, especially oil and food prices. While the primary effect of a slowdown should help relieve demand pressure, food prices spikes in 2008 and 2011 are a clear indication of how persistent these pressures are. The poor will spend even larger portions of their income on food; and

3. The third channel, and the one that is of course immediate relevance to the Development Assistance Commission (DAC), is international development finance and in particular overseas development assistance (OECD, 2013).

\section{SSA Policy Responses to the Euro Zone Debt Crisis}

While substantial differences among SSA countries emerged-based on their fiscal spaces and inflationary pressures-SSA countries responded better to this crisis than in the past. Their fiscal measures also constituted a clear break from the pro-cyclical policies during the past crises and the pre-crisis boom. The scope for counter-cyclical measures varied with the level of income though, as richer countries had a greater space for maneuver (Kasekende, Brixiovo and Ndikumana, 2010). Given the unfolding of the stocks hitting the SSA economies, the monetary and fiscal policy responses were largely reactive. The main forward-looking macroeconomic policy setting and decisions were made some years earlier, and enabled a sustained moderation in the economic effects of the crisis. Like many other emerging market economies, capital inflows and upward pressure on the exchange rates played a complicating role in how the SSA economies responded to the shocks and to policy (Kganyago, 2012).

As part of their stimulus packages, a number of governments boosted investment (infrastructure in particular) and consumption (social spending) outlays, acting as consumer of last resort (Kasekende, Brixiovo and Ndikumana, 2010). 
However, policy adjustments in most SSA countries were country-specific. It should be pointed out that SSA is not a homogeneous geographic space. It is a continent made up of countries, so the policy responses were also country-specific. For instance, in response to price shocks, few flexible exchange rate countries had to tighten monetary policy. But interest rates remain at low levels set during the financial crisis. Additionally, nominal effective exchange rates were weakened in some countries and some oil-exporting countries increased reserves sharply. Fiscal policy was loosened in many countries, including South Africa, to support growth and to finance more expansive capital investment projects. Likewise, weak control over public finances remained an issue in some countries, and needed to be countered by more aggressive institutional development, governance reforms, and human capital building (Kganyago, 2012). For example, in East Africa, in response to the inflation surge, most countries adopted monetary tightening, with sharp increases in interest rates or tighter control of money supply helping to reduce inflation expectation. Despite receding in some of these countries, inflation remained high in Ethiopia, Tanzania, and Uganda. Going forward, monetary policy remained focused on restoring price stability in countries still experiencing high inflation. In countries where inflation prospects were lower (Southern Africa countries), a more accommodative stance was advisable based on the strength of their recovery (The African Economist, 2012).

Finally, the euro zone is still muddling through, repairing the banks' balance sheets, national debt, deteriorating credit conditions and seeking to reassure market confidence. Apparently, market sentiments, unimpressed by the different measures taken so far from austerity and firewalls to the governance structures of the euro zone, continue to impose the price. There seems to be a residual feeling that the future of the euro is not yet fully secured and a clear conclusion by the markets, that structural reforms are needed, from the welfare state, to labor markets, training and innovation (Kaberuka, 2012)

\section{Recent Performance of SSA's Real Economy}

SSA's economic lions are pulling the continent into an unprecedented era of wealth creation and prosperity that is offering new opportunities for foreign capital. With year-on-year growth of between 7 percent and 9 percent, Ghana, Angola, Mozambique, Zambia, and Ethiopia have already played a pivotal role in helping Africa's economies triple in size since 2000. But the same again is expected to happen in the next 15 years, as half the continent's population migrates to urban centers and its middle class overtakes that of India. These predictions may seem excessively optimistic, but they are based on two converging and complementary forces hitting Africa like a herd of stampeding elephants: accelerated exploitation of the continent's vast natural resources, and global demographic trends that largely favor it over the rest of the world. Sub-Saharan Africa's oil production alone has surpassed 10 million barrels per day, equal to Russia or Saudi Arabia. Some six million barrels are pumped out of SSA, generating annual revenue of $\$ 235$ billion, or about 20 percent of GDP. SSA's population is young and getting younger, while demographic shift is being amplified by improvements in education and healthcare, particularly among SSA's big five economic stars: Ghana, Angola, Mozambique, Zambia, and Ethiopia (Emid, 2014). 
Generally, SSA has 62.6 billion barrels of proven oil reserves, which is just 7 percent of the volume of the region with the world's biggest reserves, the Middle East. Production averaged 5.88 million barrels per day in 2012, up from 4.6 percent in 2003, and equivalent to about 7 percent of global production (Ford, 2014). All these figures agree: SSA is the continent of the future. Growth is higher than in any other emerging economy region. Natural resources are being discovered at an ever-faster rate - the continent is likely to emerge soon as the world's biggest reserve of critical industrial resources. Demographic patterns show that SSA's human inhabitants are the youngest on the planet, meaning that its economies are likely to grow much faster than those with aging populations (Walker, 2014). Furthermore, natural resources make up a quarter or more of export revenues for around half of the 45 countries in SSA. Nine of them, including Nigeria and Angola, which have two of Africa's largest economies, benefit from the exports of oil and gas. Yet mining and oil are far from the whole story. Study published by the International Monetary Fund (IMF) finds that eight of the 12 fastest growing economies in Africa in recent years did not rely on natural resources. Together these economies grew more quickly even than the group of oil producers. To discover what lay behind this success, IMF research focused on countries that met two criteria: GDP growth of at least 5 percent a year on average from 1995 to 2010, and growth in GDP per head of at least 3 percent a year. Six countries qualified: Burkina Faso, Ethiopia, Mozambique, Rwanda, Tanzania, and Uganda. Stable and purposeful economic policymaking and reforms helped them to do so. (The Economist, 2014).

Gold has long been SSA's dominant mineral, but iron ore is exciting more interest. The region is underdeveloped and mining firm are busy exploring and discovering potential sites even as they develop new mines. Yet foreign companies will not find it easy. Infrastructure is poor, geological information scanty, land ownership often murky and institutions weak and bad leadership, especially in countries like Liberia and Sierra Leone that have been ravaged by civil war, dictatorship, and post-war endemic corruption (The Economist, 2013). Compared to other regions, SSA still garners a tiny proportion of global investment but FDI to the region is rising: up 5 percent to $\$ 56$ billion last year. The SSA mergers and acquisitions last year totaled $\$ 30$ billion generated by 1,000 deals. More than 220 private equity managers now target SSA. The African Private Equity \& Venture Capital Association says the 53 private equity deals completed last year for which it has data were worth $\$ 3.2$ billion-but still lower than SSA's 2007 peak at $\$ 4.7$ billion. The push to these markets is an out-growth of two large investment trends: a global hunt for yield and a broader narrative of rising African growth (Manson, 2014). Other trends to look out for are increased investment originating from private equity and venture capital and particularly fierce focus on SSA natural resources on the part Asian investors. China is also going to be a major investor in several mega infrastructure projects (Jacobs, 2014).

The preceding analysis provides some hope for economic growth. But what will growth mean? In some cases, SSA growth is the result of fairly high commodity prices, fairly stable economic policies, the effects of more open trade, more private investment, and especially of a population that is younger than China, India or Brazil. But in other cases, it is paradoxically, the result of terrible management. The years to come is when SSA will have to begin to 
deliver on that promise, or risk turning investors away empty-handed and discouraged - and if the past is any guide to the future, there will be plenty of bumps on the road to prosperity (Walker, 2014). Hence, the need for SSA economies to prioritize infrastructure was emphasized by the Head of the IMF, Christine Legarde, in June when she urged Africa to spend $\$ 93$ billion a year to bring its economies up to speed and improve growth (Jiwaji, 2014).

\section{SSA's Long-Term Economic Prospects}

SSA's GDP was expected to grow by 4.8 percent in 2013, slightly higher than 2012. Growth would be underpinned by expanding domestic demand, moderate to high commodity prices, increased South-South trade and investment, and investment in energy and transportation infrastructure, telecommunication, and social services (AfDB Annual Report, 2012). Generally speaking, SSA economies benefited from stronger commodity prices and greater FDI. These gains were constrained by currency appreciation in some instances, and more importantly, by rising food prices. So the crisis did feed itself through the commodity channel and the commodities were a double-edged sword for SSA economies. For example, SSA economies produce commodities that were exported to Europe, China and the rest of the world. There were significant parts of SSA that were actually importers of crude oil, and as commodities prices rose and the price of crude rose it fed itself into domestic energy prices and it also fed itself into domestic food prices (Kganyago, 2012).

Yet, depending on the magnitude and the form of the transmission mechanisms discussed above, SSA economies and people may face various negative social and economic effects as follows: (a) Reduced economic growth-Base on OECD projections of the impact of the euro area crisis on SSA, Economic Commission on Africa (ECA) estimated that SSA's GDP growth rate was likely to reduce by 0.7 percent and 1.2 percentage points in 2012 and 2013 respectively, under the OECD downside scenario. Under a scenario involving an optimal political outcome in Europe, SSA's growth rate would increase by 0.3 and 0.6 percentage points, respectively. Indeed, economic performance would clearly be affected under any of the OECD projected scenarios, owing to reduced export demand and lower commodities prices; (b) Reduced spending on social sectors---External assistance accounts for a large proportion of the funding of social sectors in SSA countries. Many countries are already experiencing difficulties in providing social goods and services, resulting in heavy reliance on aid for budgetary planning. For that reason, declines in aid flows as a result of budgetary restrictions in donor countries affected by the crisis are likely to lead to cuts in the funding of social programs, since, health, education, and other social programs targeting the most vulnerable are the most liable to suffer budget cuts; (c) Although not likely in the short term, any reduction in trade and inflows owing to the economic downturn in Europe is likely to translate into higher unemployment, vulnerability and poverty in SSA. Similarly, employment and income reductions originating in the export sector are likely to spread to other sectors. A fall in income in one sector will, via economic interdependence and negative multiplier effects, lead to a reduction in demand in other sectors, especially basic consumer goods sectors. As they experience these multiplier effects, SSA countries must also be aware of the challenges of structural changes, such as labor force growth, as well as increased 
demand in export sectors such as petroleum, gold and other minerals, set against reduced demand in other sectors such as tourism, horticulture and diamonds (UNECA, 2012).

\section{Policy Lessons and Implications for SSA's Real Economy}

The crisis presents SSA with three crucial policy lessons in its promotion of trade as key driver of sustainable growth. First, it highlights the importance of strengthening intra-SSA trade which, at its current levels, is not sufficient to counter the pro-cyclical effects of weak export demand, making the SSA venerable to external shocks. Given SSA's growing population and the corresponding expansion of its middle class, a huge market exists for intra-regional trade to service the existing domestic demand. Second, SSA governments should aim to build on the recent improvements in trade with their Southern partners. SSA's trade share with key Southern partners more than doubled in the last decade, from about 10 percent in 2000 to over 20 percent in 2009, largely reflected in the reduction in its trade share with Europe. Hence, further export destination diversification to its Southern partners will help SSA to manage the idiosyncratic risks that arise from specific regional rather than global economic shocks. Lastly, and related to the first, the crisis highlights the importance of SSA countries diversifying their export bases. A narrow export base largely composed of primary commodities limits opportunities for intra-SSA trade as countries are unable to provide the goods that SSA consumers are looking for. It also exposes SSA to commodity shocks, whose impact on growth can be debilitating, as was witness in 2009. Trade diversification will therefore help both to boost intra-rational trade and to mitigate the impact of external price shocks (UNECA, 2012).

Finally, the anticipated growth slowdown in both OECD and emerging market countries, coupled with growing uncertainties in global financial markets, is expected to negatively impact SSA economies both directly and indirectly. First, with slowing world economy and uncertainty in global financial markets, investors around the world will respond by withholding investment decisions. This in turn will directly hurt SSA economies because it will reduce exports from the continent, tourism from abroad, capital inflows and remittances. Second, as observed in 2011, uncertainties within the European financial system led to a massive shift by investors from euro-denominated assets to dollar-based assets, thereby triggering sharp depreciations in the currencies of most of the non-oil-exporting emerging countries in SSA, notably, South Africa, Kenya, Tanzania, and Uganda. For instance, between May and December 2011, the Ugandan, Kenyan, and Tanzania shillings depreciated against the dollar by 18, 13, and 7 percent, respectively (Agbor and Kamau, 2012)

\section{Policy Recommendation for SSA's Real Economy}

\subsection{Macroeconomic Stability}

SSA countries first need to protect their macroeconomic balance sheets by controlling inflation, restraining spending and ensuring that debt-to-GDP ratios are sustainable. Additionally, SSA governments need to maintain political stability, which is a crucial element to improving the business environment and attracting foreign investors (Agbor and Kamau, 2012). In the long-term, SSA economies need to diversify their export commodities as well as 
trading partners especially with China and other BRICS members (The African Economist, 2012). Likewise, SSA countries must implement policies to diversify their economies away from oil, gas, and minerals into higher value-added activities, such as agro-industries, manufacturing and services. More diversified economies are more resilient to wide demand swings caused by fluctuating commodity prices. In addition, SSA must accelerate the pace of regional integration in order to expand intra-SSA trade. Expanding trade within SSA is crucial to supporting growth especially when economic conditions will probably continue to be dismal in advanced economies (Agbor and Kamau, 2012).

\subsection{Governance}

SSA policymakers must consider three issues. First, governance matters for growth and development. Worldwide data show that faster growth and better development performance are associated with better governance, in particular with government effectiveness, regulatory quality, rule of law, and controlling corruption. The link between growth and two indicators - government effectiveness and regulatory quality - is strong. However, it is more difficult to establish a causal relationship between the two. A plausible interpretation is two-way causality between better governance quality and higher development performance: one enforces the other. Thus it pays to improve both. Second, the relevance of different elements of governance varies with a country's stage of development. Low-income countries should strive for more effective government, better regulatory quality and rule of law, and tighter control on corruption. And graduating to higher income entails improving governance quality to reap considerable rewards from their citizens' greater voice, political stability, and world-class institutions (for example, effective legal systems), high-quality health and education services, and well-developed financial systems. Third, the payoffs to governance reforms vary with individual indicators of development. Corruption prevents public service programs from reaching the poor, while weak regulatory regimes and ineffective government throw a monkey wrench into businesses' growth and infrastructure investment. As development goals in themselves, all dimensions of governance should be pursued. Hence, SSA policymakers should focus not only on what is relatively easy to implement quickly but on steps with the most visible impact on development. High-quality institutions will help fast-growing economies avoid the middle-income trap and enable slow-growing economies to establish the conditions necessary for sustainable economic growth (Jha and Zhuang, 2014).

\section{Concluding Remarks}

The outlook for 2014 and beyond for the Euro zone area is dampened by long-term constraints. Indeed, there is a looming risk of secular stagnation in many economies owing to the adverse effect on productivity growth of years of underinvestment in human and physical capital. And the structural reforms that these economies need to boost their potential growth will be implemented too slowly. While the euro zone tail risks are lower, its fundamental problems remain unresolved: low potential gravity; high unemployment; still-high and rising levels of public debt, loss of competitiveness and slow reduction in unit labor costs; and extremely tight credit rationing, owing to banks' ongoing deleveraging. Meanwhile, progress toward a banking union will be slow, while no steps will be taken toward establishing a fiscal 
union, even as austerity fatigue and political risks in the euro zone's periphery grow (Roubini, 2014).

When it comes to SSA in the past, perceptions of poverty and corruption have long dogged SSA countries looking for investment. But as growing interest in SSA's economies has morphed into a frenzy of investment, a new perception gap is appearing. Much of the enthusiasm for investing in SSA is founded on the conviction that there is huge untapped potential for domestic economic growth and that there is a rapidly swelling middle class that will drive up domestic consumption. Research by the World Bank, for example, shows middle-class consumption was responsible for more than 60 percent of the continent's overall GDP in 2012. Bain's 2012 report on SSA predicts that the continent's middle-class will double in size by 2020 (Keeler, 2014).

This will require Institutions that are more necessary for growth to reduce inequality. Most countries that have the best institutions have lower inequality. In countries where you do not have strong institutions, you can have bursts of growth but it is hard to sustain growth. This is what has been different about SSA in the last decade: A number of countries - such as Rwanda, Ethiopia, and Angola - have been able to keep 6 to 7 percent growth for 10 years. Emphasis on preserving macro stability, keeping their current-account deficits under control, is due to the fear that the tailwinds may recede or turn into headwinds, so they are able to preserve that stability and do not go into another boom-and-bust cycle (Barghini, 2014). A case in point, among frontier markets in SSA, Zambia stands out for its stable economy and its long record of strong growth. These factors have helped attract foreign investors to this copper-rich, landlocked nation of 14 million people - and they have been well-rewarded. The local stock market was the fourth-fastest growing in the world last year, rising by more than 37 percent in local currency and almost 30 percent in dollar terms (Harris, 2014).

In sum, many country variables determine the degree with which economic shocks originating from the euro zone affect SSA economies. Trade linkages play an important role in the transmission of common shocks. It is also known that economic integration, the result of lower barriers to cross-border flows of goods and services, generally facilitates the international propagation of economic shocks. Research shows that emerging economies, including those in SSA, are not helpless when it comes to responding to the ups and downs of global markets. Countries that wish to benefit from trade and financial globalization can reduce their unpleasant side effects by becoming more transparent - that is, by providing more data and in a more timely fashion, improving corporate disclosure standards, increasing the predictability of policies, and, more generally, improving governance (Brandao-Marques, Gelos, and Melgar, 2013).

Finally, based on the analyses presented in this paper, it can be said that author's contribution to existing knowledge are as follows: He provides new insights into: 1. The role of prudential policies by SSA policy-makers in reducing the negative impact of the euro zone economic crisis; 2 . The role of good governance and transparency by SSA governments in responding effectively to the euro zone crisis; 3 . The role diversification of export markets away from the euro zone to emerging markets such as China, Brazil, etc. in shielding SSA from the impact 
of the euro zone crisis; and 4. The role of fiscal flexibility in substituting for reduced development assistance from the euro zone governments to meet social spending.

\section{References}

ADB Annual Report (2012). Africa socio-economic performance. African Development Bank: Tunis, Algeria.

AfDB Brief (2012). The impact of the US credit rating downgrade and European debt crisis on Africa. African Development Bank: Tunis, Algeria.

Agbor, J. and Kamau, A. (2012). Minimizing the impact of the global economic slowdown on Africa. Washington, D. C.: The Brooking Institution. Pp. 21-22.

Barghini, T. (2014). Global salon: Sidestepping the boom and bust. Global Finance, Vol. 28, No. 1, P. 50.

Brandao-Marques, L., Gelos, G., and Melgar, N. (2013). Transparency matters. Finance \& Development, 50(4), 44-46.

Brixiova, Z., Kamara, A. B., \& Ndikumana, L. (2010). Containing the impact of the crisis and paving the way to strong recovery in Africa. AfDB Policy Brief No. 2. The African Development Group: Tunis, Algeria

Emid, A. (2014). Frontier market report: Mozambique risky, but rewarding. Global Finance, $28(4), 58$.

Ford, N. (2014). African energy the big league beckons. African Business (March), Issue No. 408, 59-77.

Harris, W. (2014). Frontier market report: Zambia's growth story. Global Finance, 28(2), 47.

Heinrich, E. (2014). Regional report Africa: The African lions roar. Global Finance, 28(5), 28-32.

Jacobs, S. (2014). Investment bonanza predicted for 2014. African Business (February), 405, 64-66.

Jha, S., \& Zhuang, J. (2014). Governance unbundled. Finance \& Development, Vol. No. Pp. 24-27.

Jiwaji, A. (2014). China outflanks Western investors. African Business (July), Issue No. 410, 30-31.

Kesedende, L., Brixiovo, Z., \& Ndikumana, L. (2010). Africa: Africa's counter-cyclical responses to the crisis. Journal of Globalization and Development, 1(1), 55-59.

Kaberuka, D. (2012). The global economy rebuilding resilience in SADC and Africa. Speech by

Source:http://www.afdb.org/news-and-events/article/the-global-economy-rebuilding-resilienc e-in-s... Accessed on July 7, 2014. 
Keeler, D. (2014). Regional focus: sub-Saharan Africa mind the gap. Global Finance, 28(1), 38-39.

Kganyago, L. (2012). The impact of the Eurozone financial crisis on African economies. South Africa Reserve Bank: Pretoria, SA.

Manson, K. (2014). Dodging bullets while investing in Africa. Financial Times (July 3).

OECD (2013). The euro zone crisis and its impact on ODA. OECD: Paris, France.

Regional Economic Outlook (2011). The International Monetary Fund: Washington, D. C.

Roubini, N. (2014). The global economy in 2014. Source: www.social-europe.eu/2014/01/global_economy_2014. Access: July 22, 2014.

The Economist (2014). Africa's population: Can it survive such speedy growth? August 23: Vol. 412, No. 8901, 39-40.

The Economist (2013). No need to dig: Many of Africa fastest-growing economies have not relied on oil or mining. November 2: Vol. 409, No. 8860, 70.

The African Economist (2012). The impact of the euro zone crisis on Africa. Pp. 1-6.

UNECA (2012). The impact of the European debt crisis on Africa's Economy: A background paper (E/ECA/CM/45/3). Addis Ababa: ECA.

Walker, R. (2014). Africa's ugly sisters. African Business, (June) Issue No. 409, 22-24.

Weidmann, J. (2012). Rebalancing Europe. Speech at the Chatham House, London, March 28, 2012.

Wolf, M. (2012). The German response. Financial Times. June 7. Accessed August 20, 2014. http://blogs.ft.com/martin-wolf-exchange/2012/06/07/the -german-response

\section{Copyright Disclaimer}

Copyright for this article is retained by the author(s), with first publication rights granted to the journal.

This is an open-access article distributed under the terms and conditions of the Creative Commons Attribution license (http://creativecommons.org/licenses/by/3.0/). 